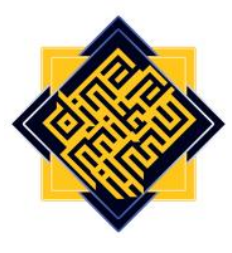

\title{
Favouritism Behaviours of School Administrators: Teachers' Perceptions of the Secondary Schools in Turkey
}

\author{
Abidin Dağlı \\ Dicle University, Turkey \\ e-mail:dagli@dicle.edu.tr \\ Zühal Akyol \\ Ministry of National Education, Turkey \\ e-mail:celebi.zuhal@hotmail.com
}

\section{Abstract}

This study aims to determine favouritism behaviors of school administrators according to public secondary school teachers' perceptions in terms of some variables. The sample of the study consisted of 22 schools selected randomly from the population and 376 teachers employed in these schools. "Favoritism in the School Management Scale" was used in this research. In the study, teachers stated that favouritism behaviors in their schools are at the "sometimes" level. According to perceptions of teachers, the highest three items in the favouritism scale are: "(1) In the preparation of teachers' weekly lesson plan ( $\bar{X}=3,30 ;$ Sometimes)", "(2) In the planning of lesson distribution ( $\bar{X}=3,12$; Sometimes)", "(3) Taking into consideration the complaints of teachers ( $\bar{X}=3,08$; Sometimes)". The lowest three items in the favouritism scale are: (1) Among the teachers in their hometowns ( $\bar{X}=2,14$; Rarely); (2) Related to the branches of the teachers ( $\bar{X}=2,38$; Rarely) and (3) Related to the gender of the teachers $(\bar{X}=2,43 ;$ Rarely). No significant difference was detected with respect to the teachers' educational background, gender, marital status, professional experience, and union on the perceptions of favouritism behaviours. Nevertheless, a significant difference was found in all dimensions and throughout the whole scale of favouritism regarding to school size (the number of teachers) variable.

Keywords: cronyism, favourtism, patronage, school management, secondary school 


\section{Abidin Dağlı and Zühal Akyol}

\section{A. Introduction}

In society, there are rules such as rules of Law, Ethics, Religious Rules, and etiquette that regulate social life and shape human behavior. However, these rules are changed through a process called "political corruption". Political corruption, in general terms, is the pollution that occurs in society. That is, people act in contravention of their thinking, attitudes and behavior, traditions, general morality, understanding of legitimacy, and the rules of law governing society. Favoritism is one of the types of political corruption that occurs during the implementation of political decisions (Turgut, 2007: 1-8).

Favoritism is the choice of a person not because he/she does a job best, but because he/she is in an approved group, or because of some of his / her membership or likes (Nadler \&Schulman, 2006). Nepotism can be referred to as"the distribution of political favoritism and civil service cadres among adherents as spoils, the way of political reward and formation of partisan cadres" (Yıldırım, 2013). Favoritism is when a person is treated differently, not because of his or her competence or performance in his or her job, but because of a number of personal interests (Aydoğan, 2009: 2).

According to Lee (2008), in a nepotistic relationship, there is a situation where both sides (favoring and favored) can gain something, but everyone else loses it (cited in Demaj, 2012: 24). When the definitions related to the concept of favoritism are examined, it is observed that by pointing to injustice, injustice, and lawlessness, there is a question of favouring, supporting, and rewarding individuals or a group for reasons such as kinship, cofriend, friendship relations and political reasons (Aydın, 2015: 60).

The fact that favouritism is so common in a society may affect children growing up in that community. Even in children raised with favouritism culture, psychological problems such as "lack of self-confidence, inferiority complex, feeling inadequate" are observed to relapse. Children who are constantly brought up with favoritism cannot cope with the difficult obstacles of life when they are separated from their nepotist parents and cannot get rid of the needy syndrome. Such children, no matter how financially supported, will not be able to get rid of the psychology of "being ready" which is imparted by favoritism culture and this situation will bring about various traumatic ailments (Biber, 2016: 60).

In the work environment, in case of an inequality between the contribution made and the share received, employees get the perception that they are working in an unfair environment. The lack of confidence that occurs under these circumstances negatively affects job satisfaction, motivation, organizational commitment, and performance. In particular, the fact that the wage system is in a way that favors someone causes employees to completely break away from the organization (Büte, 2009: 737). In addition, being unresponsive to favorutism activities can be shown as an example of the corruption of institutions (Biber, 2016: 61, 62).

The advanced level of politicization in the administration undermines the impartiality of the administration, and the frequent replacement of especially the senior managers impairs consistency, stability and continuity in the administration. As a result of this, public administration does not function effectively and efficiently, and corruption occurs in the management system (Çevikbaş, 2006: 277). When favouritism occurs in the workplace, it 
should be dealt with it when it first appears. If it is neglected for a while, it may cause reactions such as dislike of other employees, retention of information, frequent discussions leading to a boring work environment, distrust, and anger towards the manager and colleagues (Ramanchander, 2011).

In this study, the types of favoritism suggested by Meriç and Erdem (2013) and thought to be widespread in public institutions are discussed and explained briefly below.

1. Favoritism of Relatives (Nepotism): It is possible to describe it as the practice of unfairly giving the best jobs to your acquaintances while in a position of power (Longman, 2004: 1101). According to Podgete and Morris (2005), individuals whose superiors are hired with nepotism to have low organizational commitment, and those hired with nepotism may expose to negative reactions by their co-workers (cited in van Hooft \& Stout, 2012: 78).

2. Favoritism of Co-Friends (Cronyism): Cronyism is a type of favouritism in which cofriend relations are taken into consideration instead of merit and equality principles in hiring public officials (Özsemerci, 2003: 29). In general, cronyism is the favourtism shown to co-friends/ acquaintances, regardless of the characteristics sought. Decisions are often made based on who is loved. For instance, an employee who performs very well cannot benefit from situations such as salary increases or promotions. Because the person who is responsible favours another person due to their friendship relationship (Khatri, Tsang \& Begley, 2006). Coco and Lagravinese (2014) also stated that there is a relationship between cronyism and educational performance, and that schooling activities may not be very productive because of the existence of cronyism in some countries. Because cronyism causes workers to make less effort. The presence of cronyism reduces the impulses in acquiring educational cognitive skills.

3. Political Favouritism (Partisanship): It is is the way in which political parties provide unfair benefits to the voters who supported them by performing privileged actions in various ways after they came to power (Özsemerci, 2003: 29). When public officials are engaged in biased conduct, it is not only contrary to ethical values but is also a crime according to the law. Public officials are prohibited from treating people differently for reasons such as language, religion, color, race, political thought, philosophical belief, sect, personal intimacy, and so on (Kartal \& Demirhan, 2009: 169).

4. Favoritism of Service: It is the political power to allocate budget allocations to its own constituencies in order to maximize their votes and thus plunder budget resources in order to remain in power again in the upcoming elections (Tarhan, et al., 2006: 31; Özsemerci, 2003: 29, 30). The fact that some constituencies incurred the wrath of those parties for not voting or giving little to the political party in power is actually an indication of favoritism of Service (Key, 1994; cited in Özkanan \& Erdem, 2014: 197).

5. Patronage: In the political process, it is referred to as "patronage" in the literature that political parties dismiss "senior bureaucrats" who work in public institutions and institutions after they come to power and appoint new people to these positions based on factors such as political solidarity, ideology, nepotism and cronyism (Özsemerci, 
2003:30; Tarhan, et al., 2006: 31). It means being protected or supported by someone who is in a top position (Karakaş \& Çak, 2007: 78).

6. Sexual Favoritism: It occurs when an administrator gives a promotion or privilege to his or her staff with whom he or she has a romantic relationship. Nevertheless, these privileges are not provided to other members who are more qualified. These and similar events in the workplace can give employees the feeling that sexuality is more important than work and productivity. This, of course, may cause demoralization in the work environment and will also lead to feelings of anger and jealousy of the employees towards their coworkers who prioritize their sexuality (Sheridan, 2007: 383, 384).

Some similar research has been conducted in the literature regarding favoritism behaviors of school administrators. For example; in Turkey and abroad some research has been done by Avetisyan and Khachatryan (2014), Coco and Lagravinese (2014), Nabiryo (2016), Akan and Zengin (2018), Tabancalı (2018), Güner (2019), Kolukırık (2019), Demirtaş and Demirbilek (2019), Gülay and Kahveci (2020), Cesur and Erol (2020), Kahraman (2020), and Gider (2020).

All in all, favoritism is actually a threat that prevents employees from taking a positive attitude towards the organization in which they work. When it is thought that favoritism will be done by the administrators in the school environment, teachers who dedicate almost their entire life to the enlightenment of society and humanity will have problems in their relations with their school administrators and colleagues due to the favoritism that has become almost a problem of the age. Therefore, there will be a decrease in the working performance of the teachers and a decrease in their commitment to the organization. With this research, favoritism behaviors of secondary school administrators based on the perceptions of teachers in public secondary schools were studied. It is hoped that the research will contribute to the prevention of favoritism in schools and to the work of teachers in a healthier school environment, as well as shed light on the administrators, teachers and the researchers who will conduct research on this subject.

\section{The Purpose of the Research}

The aim of this study was to determine whether teachers in public secondary schools' perceptions of favoritism behavior of their own school administrators made a significant difference according to some variables. For this basic purpose, the research questions are as follows:

1. How does the perception of teachers in secondary schools about the favoritism behaviors of their own school administrators spread?

2. Does the perception of teachers in secondary schools regarding the favoritism behaviors of their school administrators make a significant difference according to some variables, such as "state of education", "gender", "size of school" and "membership in any union"? 


\section{B. Literature Review}

Under this subheading, some research findings on favoritism in educational institutions both in Turkey and in countries outside Turkey are summarized below.

A study was conducted by Avetisyan and Khachatryan (2014) to reveal teachers' perceptions of nepotism as one of professional honesty and non-professional activities in public schools in Armenia. At the end of the research, it was observed that teachers gave their colleagues ' children higher grades than they deserved or helped them cheat during exams. This is a clear example of nepotism as well as a violation of professional integrity. Research data show that this behavior is part of the institutional culture of schools and is considered a normative behavior.

In a study (Coco \& Lagravinese, 2014) conducted in schools, but in which favoritism affects educational performance in terms of students, it was concluded that favoritism negatively affects relations among students and hinders success and that the best way to improve performance in schools is to increase transparency in education and relations and to give up favoritism practices.

A study by Nabiryo (2016) examined how nepotism affects organizational performance in schools. As a result of the research, it was found that the practice of nepotism in schools is intense, creates tension in the working environment and also negatively affects performance. But interestingly, it has emerged that it has brought with it a sense of job security and belonging to the institution from the point of view of the favoured part. It was found that this had a reverse situation in teachers who were subjected to nepotism, decreased productivity and demoralized.

As a result of the research conducted by Akan and Zengin (2018) on teachers in schools, it was found that according to the perceptions of teachers, the organizational trust levels of teachers in primary schools were high, and the level of favoritism attitude and behavior of school administrators was low, and there was a moderate, negative and significant relationship between the organizational trust levels of teachers and the favoritism levels of administrators.

Tabancalı (2018) conducted his study, called favoritism in primary schools, on 361 teachers. At the result of the research, teachers stated that in general, that is, on a scale basis, there was no favoritism in their schools. There wasn't any significant difference between the views of teachers according to the form of employment, gender, and union membership. However, according to the phases of a career, it was found that there was a significant difference between the start-up phase and other phases, and according to the branch variable, between the views of the classroom teachers and the teachers of the branch.

Güner (2019) investigated the relationship between favoritism behavior of school administrators in public Anatolian high schools and the life satisfaction of teachers. 350 teachers constitute the sample of the study. In the study, teachers stated that principals in their schools generally engaged in favoritism behavior at the "rarely" level. According to teacher perceptions, the behavior that school principals display at the highest level related 


\section{Abidin Dağlı and Zühal Akyol}

to favoritism "is related to the preparation of weekly course schedule of teachers (at the level of sometimes). The behavior they show at the lowest level is " related to the distinction between teachers, based on their hometown (at the level of rarely). A significant difference in the dimensions of "planning" and "organizing" was found between teachers ' perceptions of favoritism only according to the variable "school size (according to the number of teachers)". In addition, the study found no significant association between the favoritism behaviors of school administrators and the life satisfaction of teachers.

392 teachers were included in the sample of a study, titled "teacher perceptions of favoritism behaviors of school administrators", conducted by Kolukırık (2019). According to teacher perceptions in the study, favoritism behaviors in the planning, organization, coordination and evaluation processes of school administrators were determined at the level of "never".

The research conducted by Demirtaş and Demirbilek (2019) on the effect of favoritism behaviors of school principals according to teachers' perceptions. The research consisted of 16 school principals and 68 teachers. In the analysis, teachers' views on how favoritism will affect confidence in principals were collected under the theme of "my trust is shaken"; on the other hand, the principal's views were collected under the theme of "distrust".

Gülay and Kahveci (2020) aimed to determine the relationship between teachers' perceptions of favoritism in school management and organizational trust levels. In the study, it was determined that there is a moderate negative relationship between favoritism and organizational trust according to teachers' opinions.

The research of Cesur and Erol, (2020) determined the relationship between teachers' perceptions of favoritism in school management and their perceptions of organizational justice. The study found low level negative significant relationships among all dimensions (planning, organizing, coordination and evaluation) that determine teachers' perception of favoritism and organizational justice in school management.

In his study, Kahraman (2020) used the basic qualitative research design to determine the favoritism behaviors of school principals and the effects of these behaviors on teachers, and formed a working group of 16 teachers who were selected with the purposeful sampling method of the study. In the study, it was found that favoritism practices in schools negatively affected teachers' feelings of justice, the desire to leave, and had a negative impact on performance.

Gider (2020) took 409 teachers to the sample of the study to determine whether there is a relationship between favoritism behaviors displayed in school administration and teachers' level of alienation from work. The results of the research show a positive and moderately significant relationship between favoritism in school administration and teachers' job alienation levels.

\section{Research Methodology}

This section focuses on the model of research, the universe and sample, data collection tool and analysis of the data, respectively. 


\section{Research Design}

This research is conducted as a survey study. In survey model studies, the person, and event or object that is the subject of the research is tried to be defined in accordance with their own conditions (Karasar, 2006: 77).

\section{Participants of the Study}

In the 2016-2017 academic year, teachers working in secondary schools in the Central districts of Diyarbakır /Turkey were determined as the population of this research. There are a total of 64 secondary schools in the central districts of Diyarbakir and a total of 3403 teachers are employed in these schools. In the study, random (chance) method, one of the sampling methods, was used. The sample of the study consisted of 22 schools selected by random method from the population and 376 teachers employed in these schools. While determining the school size of the teachers involved in the study, Jones (1997)'s classification was taken as a basis. According to this, schools with 28 and fewer teachers were considered as small schools, schools with 29-39 teachers as medium-sized schools, and schools with 40 and more teachers as large schools. Of teachers surveyed, $84.9 \%$ graduated with a bachelor's degree and $15.1 \%$ graduated with a master's degree, $41.8 \%$ were female and $58.2 \%$ were male. Of the schools served by teachers, $17.0 \%$ were small schools, $33.8 \%$ were medium-sized schools, and $49.2 \%$ were large schools. $60.1 \%$ of teachers have union membership, while $39.9 \%$ do not have any union membership.

\section{Instruments}

In this study, the "favoritism in school administration" scale developed by Erdem and Meriç (2012) was used as a measurement tool for data collection. The validity and reliability of this scale were determined by the researchers and applied to teachers in many public schools. In the scale there are 4 dimensions and totally 25 items. The first dimension of the scale, Planning, consists of 4 Items (1-4), the second dimension, Organization, consists of 7 items (5-11), the third dimension, Coordination, contains 5 items (12-16) and the fourth dimension, Evaluation, includes 9 items (17-25). The answers to the questions in the measuring instrument are rated as "always (5)", "most of the time (4)", "sometimes (3)", "rarely (2)" and "never (1)". Cronbach Alpha internal consistency coefficients of the "Favoutism scale in school management" used in this study were determined as, 91 for the "planning" dimension; ,95 for the "organization" dimension; ,93 for the "Coordination" dimension; , 94 for the "evaluation" dimension; and ,97 for the entire scale.

\section{Data Analysis Techniques}

In the analysis of the data, mean and standard deviation coefficient calculations were used to determine the distribution of teachers' favoritism scores in response to the first subgoal. In the second sub-objective of the study, favoritism scores were examined in terms of (1) state of education, (2) gender, (3) size of the school they were in, and (4) membership of any union. In this analysis, the normality of favoritism scores for each variable was first examined with Kolmogorov Smirnov and column graphs and it was observed that the data 
Abidin Dağlı and Zühal Akyol

in all independent variables was not normally distributed. According to this, nonparametric tests for variables were analyzed using Mann Whitney-U and Kruskall Wallis-H tests. The level of significance was taken as.05.

While interpreting means for items on the scales, the mean values between 1.00 and 1.79 are considered to be at the level of "never"; mean values between 1.80 and 2.59 are "rarely"; mean values between 2.60 and 3.39 are "sometimes"; mean values between 3.40 and 4.19 are "most of the time" and mean values between 4.20 and 5.00 are thought to be "always".

\section{Findings}

In this section, respectively; (1) how the perceptions of teachers in secondary schools about the favoritism behavior of their school administrators are distributed, (2) whether the perceptions of teachers in secondary schools regarding their school administrators ' favoritism behavior make a significant difference according to the variables such as "state of education", "gender", "size of school they are in" and "membership in any union"; is given.

\section{Distribution of Perceptions of Teachers in Secondary Schools about Favoritism Behavior of Their Own School Administrators}

Means and standard deviation scores and levels of teachers' perceptions of favoritism behavior of their school administrators are presented in Table 1.

Table 1. Distribution of Teachers' Perceptions of Favoritism Behavior of Their Own School Administrators

\begin{tabular}{lllll}
\hline & & $\bar{X}$ & Sd & Level \\
\hline 1 & In the preparation of weekly curriculum of teachers & 3,295 & 1,209 & Sometimes \\
\hline 2 & In the preparation of teachers ' watch llists & 3,008 & 1,396 & Sometimes \\
\hline 3 & In the planning of class distribution & 3,059 & 1,242 & Sometimes \\
\hline 4 & In the planning of course delivery & 3,122 & 1,311 & Sometimes \\
\hline 5 & In the assignment of teachers on social club work & 2,758 & 1,274 & Sometimes \\
\hline 6 & In the assignment of teachers on specific days and weeks & 2,814 & 1,270 & Sometimes \\
\hline 7 & $\begin{array}{l}\text { In the appointment of teachers in the boards formed at the } \\
\text { school }\end{array}$ & 2,872 & 1,256 & Sometimes \\
\hline 8 & In the division of labor among teachers & 2,995 & 1,280 & Sometimes \\
\hline 9 & $\begin{array}{l}\text { In giving teachers additional tasks related to education and } \\
\text { training }\end{array}$ & 3,043 & 1,232 & Sometimes \\
\hline 10 & $\begin{array}{l}\text { In assigning teachers to participate in events and activities to } \\
\text { be held in the school }\end{array}$ & 3,032 & 1,245 & Sometimes \\
\hline 11 & In the distribution of tasks in school (inn terms of the workload) & 3,037 & 1,306 & Sometimes \\
\hline 12 & $\begin{array}{l}\text { The rule violations of teachers (such as dress code, not } \\
\text { attending a ceremony) }\end{array}$ & 2,793 & 1,368 & Sometimes \\
\hline 13 & $\begin{array}{l}\text { Teachers getting into/out of class on time or late } \\
2,955\end{array}$ & 1,372 & Sometimes \\
\hline
\end{tabular}


Favouritism Behaviours of School Administrators

\begin{tabular}{lllll}
\hline 14 & Among teachers who do not do their duties properly & 2,995 & 1,384 & Sometimes \\
\hline 15 & In allowing teachers & 2,981 & 1,390 & Sometimes \\
\hline 16 & In taking into consideration teachers ' complaints & 3,082 & 1,399 & Sometimes \\
\hline 17 & Related to unions in which teachers are members & 2,742 & 1,504 & Sometimes \\
\hline 18 & About the genders of teachers & $\mathbf{2 , 4 3 1}$ & $\mathbf{1 , 3 5 7}$ & Rarely \\
\hline 19 & About the political views of teachers & $\mathbf{2 , 6 3 3}$ & $\mathbf{1 , 5 5 4}$ & Sometimes \\
\hline 20 & Among teachers, according to their professional seniority & $\mathbf{2 , 5 9 3}$ & $\mathbf{1 , 3 0 5}$ & Rarely \\
\hline 21 & Among teachers, according to their hometowns & $\mathbf{2 , 1 3 8}$ & $\mathbf{1 , 2 4 7}$ & Rarely \\
\hline 22 & About the branches of teachers & $\mathbf{2 , 3 7 8}$ & $\mathbf{1 , 2 6 1}$ & Rarely \\
\hline 23 & In giving teachers performance evaluation points & $\mathbf{2 , 9 1 8}$ & $\mathbf{1 , 5 1 1}$ & Sometimes \\
\hline 24 & In offering teachers to be awarded & $\mathbf{3 , 0 1 6}$ & $\mathbf{1 , 5 0 0}$ & Sometimes \\
\hline 25 & In the appointment of teachers who disrupt their duties & $\mathbf{2 , 8 9 1}$ & $\mathbf{1 , 4 2 2}$ & Sometimes \\
\hline & The Whole Scale Mean & $\mathbf{2 , 8 6 3}$ & $\mathbf{1 , 3 4 4}$ & Sometimes
\end{tabular}

As seen in Table 1, teachers participated in the total mean of the favoritism scale ( $\bar{X}$ $=2.86)$ at the "sometimes" level. The first three items with the highest mean according to teachers' perceptions are; (1) "in the preparation of weekly curriculum of teachers ( $\bar{X}=3.30$; sometimes)", (2) "in the planning of course delivery ( $\bar{X}=3.12$; sometimes)", and (3) "taking into consideration teachers' complaints ( $\bar{X}=3.08$; sometimes)".

The first three items with the lowest mean are respectively (1) among teachers, according to their hometowns ( $\bar{X}=2.14$; rarely)", (2) " related to the branches of teachers ( $\bar{X}=2.38 ;$ rarely)", and (3) "related to the genders of teachers ( $\bar{X}=2.43$; rarely)".

1. How does the perception of teachers in secondary schools about the favoritism behaviors of their own school administrators spread?

2. Does the perception of teachers in secondary schools regarding the favoritism behaviors of their school administrators make a significant difference according to some variables, such as "state of education", "gender", "size of school" and "membership in any union"?

2. The Findings as to Whether the Perceptions of Teachers in Secondary Schools Regarding Their School Administrators' Favoritism Behavior Constitute a SignificantDifference

2.1. Teachers' Perceptions of Favoritism Behavior of Their Own School Administrators According to the State of Education

The Mann Whitney $U$ test was used to determine if there was a significant difference in teachers ' perceptions of favoritism based on state of education and the findings are given in Table 2. 
Abidin Dağlı and Zühal Akyol

Table 2. Mann Whitney U Test Results of Teachers' Perceptions of Favoritism According to State of

\begin{tabular}{|c|c|c|c|c|c|c|c|}
\hline \multicolumn{8}{|c|}{ Education } \\
\hline & $\begin{array}{ll}\text { State of } \\
\text { Education }\end{array}$ & $\mathrm{n}$ & $\begin{array}{l}\text { Rank } \\
\text { mean }\end{array}$ & Rank Total & $U$ & Z & $\mathbf{P}$ \\
\hline \multirow{2}{*}{ Planning } & Graduate & 315 & 184,56 & 58135,50 & \multirow{2}{*}{8365,500} & \multirow{2}{*}{,- 617} & \multirow{2}{*}{0,537} \\
\hline & Post Graduate & 56 & 194,12 & 10870,50 & & & \\
\hline \multirow{2}{*}{ Organization } & Graduate & 315 & 184,31 & 58057,00 & \multirow{2}{*}{8287,000} & \multirow{2}{*}{,- 722} & \multirow{2}{*}{0,470} \\
\hline & Post Graduate & 56 & 195,52 & 10949,00 & & & \\
\hline \multirow{2}{*}{ Coordination } & Graduate & 315 & 183,85 & 57911,50 & \multirow{2}{*}{8141,500} & \multirow{2}{*}{-919 } & \multirow{2}{*}{$0,35^{8}$} \\
\hline & Post Graduate & 56 & 198,12 & 11094,50 & & & \\
\hline \multirow{2}{*}{ Evaluation } & Graduate & 315 & 182,26 & 57411,00 & \multirow{2}{*}{7641,000} & \multirow{2}{*}{$-1,595$} & \multirow{2}{*}{0,111} \\
\hline & Post Graduate & 56 & 207,05 & 11595,00 & & & \\
\hline \multirow{2}{*}{$\begin{array}{l}\text { The Whole } \\
\text { Scale }\end{array}$} & Graduate & 315 & 183,26 & 57725,50 & \multirow{2}{*}{7955,5} & \multirow{2}{*}{$-1,169$} & \multirow{2}{*}{0,242} \\
\hline & Post Graduate & 56 & 201,44 & 11280,50 & & & \\
\hline
\end{tabular}

As seen in Table 2, it was found out that teachers ' perceptions of favoritism did not differ significantly according to their state of education.

\subsection{Teachers' Perceptions of Favoritism Behaviour of Their Own School Administrators According to Gender}

The Mann Whitney $U$ test was used to determine whether teachers ' perceptions of favoritism according to gender made a significant difference and the findings were given in Table 3.

Table 3: Mann Whitney U Test Results of Teachers' Perceptions of Favoritism According to Gender

\begin{tabular}{|c|c|c|c|c|c|c|c|}
\hline & Gender & $\mathbf{n}$ & $\begin{array}{l}\text { Rank } \\
\text { mean }\end{array}$ & Rank Total & $U$ & Z & $\mathbf{P}$ \\
\hline \multirow{2}{*}{ Planning } & Female & 157 & 186,97 & 29355,00 & \multirow{2}{*}{16952,000} & \multirow{2}{*}{,- 231} & \multirow{2}{*}{0,817} \\
\hline & Male & 219 & 189,59 & 41521,00 & & & \\
\hline \multirow{2}{*}{ Organization } & Female & 157 & 186,87 & 29339,00 & \multirow{2}{*}{ 16936,000 } & \multirow{2}{*}{,- 246} & \multirow{2}{*}{0,806} \\
\hline & Male & 219 & 189,67 & 41537,00 & & & \\
\hline \multirow{2}{*}{ Coordination } & Female & 157 & 192,54 & 30229,00 & \multirow{2}{*}{16557,000} & \multirow{2}{*}{,- 611} & \multirow{2}{*}{0,541} \\
\hline & Male & 219 & 185,60 & 40647,00 & & & \\
\hline \multirow{2}{*}{ Evaluation } & Female & 157 & 194,98 & 30612,00 & \multirow{2}{*}{16174,000} & \multirow{2}{*}{,- 980} & \multirow{2}{*}{0,327} \\
\hline & Male & 219 & 183,85 & 40264,00 & & & \\
\hline \multirow{2}{*}{$\begin{array}{l}\text { The Whole } \\
\text { Scale }\end{array}$} & Female & 157 & 190,87 & 29967,00 & \multirow{2}{*}{16819,00} & \multirow{2}{*}{$-0,35^{8}$} & \multirow{2}{*}{0,720} \\
\hline & Male & 219 & 186,80 & 40909,00 & & & \\
\hline
\end{tabular}

As shown in Table 3, there was no significant difference between teachers ' perceptions of favoritism according to gender.

\section{3. Teachers' Perceptions of Favoritism Behavior of Their Own School Administrators According to the Size of the School They Are In}

The Kruskal-Wallis test was used to determine if there was a significant difference between teachers' perceptions of favoritism based on the size of the school they were in and the consequences were given in Table 4 below. 
Favouritism Behaviours of School Administrators

Table 4.Kruskal-Wallis Test Results of Teachers' Perceptions of Favoritism According To the Size of the School

\begin{tabular}{|c|c|c|c|c|c|c|c|}
\hline Dimensions & School Size & n & $\begin{array}{l}\text { Rank } \\
\text { mean }\end{array}$ & df & $\chi^{2}$ & $\mathbf{P}$ & $\begin{array}{l}\text { Source of } \\
\text { Difference }\end{array}$ \\
\hline \multirow{3}{*}{ Planning } & 1.Small School & 64 & 164,31 & \multirow{3}{*}{2} & \multirow{3}{*}{58,180} & \multirow{3}{*}{0,001} & \multirow{3}{*}{$\begin{array}{l}2 \text { and } 1 \\
2 \text { and } 3\end{array}$} \\
\hline & 2.Middle-Sized School & 127 & 248,00 & & & & \\
\hline & 3.Big School & 185 & 156,02 & & & & \\
\hline \multirow{3}{*}{ Organization } & 1.Small School & 64 & 179,32 & \multirow{3}{*}{2} & \multirow{3}{*}{46,174} & \multirow{3}{*}{0,001} & \multirow{3}{*}{$\begin{array}{l}2 \text { and } 1 \\
2 \text { and } 3\end{array}$} \\
\hline & 2.Middle-Sized School & 127 & 240,48 & & & & \\
\hline & 3.Big School & 185 & 155,99 & & & & \\
\hline \multirow{3}{*}{ Coordination } & 1.Small School & 64 & 172,35 & \multirow{3}{*}{2} & \multirow{3}{*}{60,870} & \multirow{3}{*}{0,001} & \multirow{3}{*}{$\begin{array}{l}2 \text { and } 1 \\
2 \text { and } 3\end{array}$} \\
\hline & 2.Middle-Sized School & 127 & 248,84 & & & & \\
\hline & 3.Big School & 185 & 152,66 & & & & \\
\hline \multirow{3}{*}{ Evaluation } & 1.Small School & 64 & 175,77 & \multirow{3}{*}{2} & \multirow{3}{*}{80,878} & \multirow{3}{*}{0,001} & 1 and 3 \\
\hline & 2.Middle-Sized School & 127 & 257,41 & & & & 2 and 1 \\
\hline & 3.Big School & 185 & 145,60 & & & & 2 and 3 \\
\hline \multirow{3}{*}{$\begin{array}{l}\text { The Whole } \\
\text { Scale }\end{array}$} & 1.Small School & 64 & 175,02 & \multirow{3}{*}{2} & \multirow{3}{*}{73,640} & \multirow{3}{*}{0,001} & \multirow{3}{*}{$\begin{array}{l}1 \text { and } 3 \\
2 \text { and } 1 \\
2 \text { and } 3\end{array}$} \\
\hline & 2.Middle-Sized School & 127 & 254,47 & & & & \\
\hline & 3.Big School & 185 & 147,88 & & & & \\
\hline
\end{tabular}

When Table 4 was examined, a significant difference was found between teachers ' perceptions of favoritism according to the size of the school they were in, in all sizes and on all scales.

\section{4. Teachers' Perceptions of Favoritism Behaviour of Their Own School Administrators Based on Membership in Any Union}

The Mann Whitney $U$ test was used to determine if there was a significant difference between teachers ' perceptions of favoritism by union membership and the findings were given in Table 5 below.

Table 5. Mann Whitney U Test Results of Teachers' Perceptions of Favoritism by Union Membership

\begin{tabular}{|c|c|c|c|c|c|c|c|}
\hline & $\begin{array}{l}\text { Union } \\
\text { Membership }\end{array}$ & $\mathrm{n}$ & $\begin{array}{l}\text { Rank } \\
\text { mean }\end{array}$ & $\begin{array}{l}\text { Rank } \\
\text { Total } \\
\end{array}$ & $\mathbf{U}$ & Z & $\mathbf{P}$ \\
\hline \multirow{2}{*}{ Planning } & Yes & 226 & 189,48 & 42822,50 & \multirow{2}{*}{16728,500} & \multirow{2}{*}{,- 215} & \multirow{2}{*}{0,829} \\
\hline & No & 150 & 187,02 & 28053,50 & & & \\
\hline \multirow{2}{*}{ Organization } & Yes & 226 & 188,75 & 42657,50 & \multirow{2}{*}{16893,500} & \multirow{2}{*}{,- 055} & \multirow{2}{*}{0,956} \\
\hline & No & 150 & 188,12 & 28218,50 & & & \\
\hline \multirow{2}{*}{ Coordination } & Yes & 226 & 191,66 & 43314,50 & \multirow{2}{*}{16236,500} & \multirow{2}{*}{,- 692} & \multirow{2}{*}{0,489} \\
\hline & No & 150 & 183,74 & 27561,50 & & & \\
\hline \multirow{2}{*}{ Evaluation } & Yes & 226 & 190,19 & 42983,50 & \multirow{2}{*}{16567,500} & \multirow{2}{*}{,- 371} & \multirow{2}{*}{0,711} \\
\hline & No & 150 & 185,95 & 27892,50 & & & \\
\hline \multirow{2}{*}{$\begin{array}{l}\text { The Whole } \\
\text { Scale }\end{array}$} & Yes & 226 & 190,18 & 42981,50 & \multirow{2}{*}{16569,50} & \multirow{2}{*}{,- 369} & \multirow{2}{*}{0,712} \\
\hline & No & 150 & 185,96 & 27894,50 & & & \\
\hline
\end{tabular}


Abidin Dağlı and Zühal Akyol

As shown in Table 5, there was no significant difference between teachers ' perceptions of favoritism compared to their membership in any union.

\section{E. Discussion}

In this section, the results obtained in this study are interpreted and discussed in connection with the results of other studies on research topics.

In this research, teachers participated in the total mean of the favoritism scale at the "sometimes" level. In a research conducted by Meriç (2012), it was found that "according to teachers' perceptions, school administrators show favoritism at the level of "rarely". On the other hand, in the research by Polat and Kazak (2014), Karademir (2016), Akan and Zengin (2018), Gülay and Kahveci (2020), Gider (2020), and Erdem, Aytaç and Gönul (2020), it was found that nepotism attitudes and behaviors of school administrators were "low" according to teacher perceptions. As can be seen, it can be said that the research results are too close with each other. Favoritism can be defined as a tendency to deviate from right and justice in favor of a person or group (Erdem, 2010:1). This finding in the current study shows that school administrators sometimes tend to deviate from rights and justice. As Çelik and Erdem (2012: 28) says, believing that favoritism exists in an organization can have some negative consequences for the employees of the organization. It can reduce employee performance, reduce organizational commitment, increase stress, and create job dissatisfaction. Therefore, as suggested by Ramanchander (2011), the problem of favoritism should be tried to be solved at the first stage. Otherwise, this can result in reactions such as other employees' disliking the workplace, withholding information, frequent discussions in the workplace, distrust, taking an attitude towards the boss or the favoured employee, etc.

The first three items with the highest mean of nepotism according to teachers ' perceptions are: (1) "preparing teachers' weekly course schedules, (2) "planning the course distribution, and (3) "taking into account teachers' complaints. The first three items with the lowest mean of nepotism are, respectively; (1) "among teachers, according to their country (2), "related to the branches of teachers, and (3) "related to the gender of teachers. Also, in the study conducted by Güner (2019), the first item with the highest mean according to teachers 'perceptions is favoritism in the preparation of teachers' weekly course schedule, and the article with the lowest mean is favoritism among teachers according to their hometown.

In a study conducted by Meriç (2012), almost similar conclusions were reached according to teacher perceptions. In a study by Pounder and Blase (1988), which examined favoritism of school principals, a large majority of teachers (66\%) stated that the feeling they felt because of favoritism of the principal was "anger". $14 \%$ of teachers felt "depression", 11\% felt anxiety, and $8 \%$ said they accepted this condition (Pounder \& Blase, 1988: 5).

It was found that teachers 'perceptions of favoritism according to their "state of education" did not differ significantly in the dimensions of planning, organization, coordination and evaluation. Similarly, in a study conducted by Güner (2019), there was no significant difference between the perceptions of teachers according to their state of 
education. In other words, it can be said that teacher views are similar to each other in all dimensions.

There was no significant difference between teachers' perceptions of favoritism in terms of their "gender." In this respect, the fact that there is no difference between the views of female and male teachers indicates that school administrators follow a policy regardless of gender in their practice. This finding is similar to the results of the study conducted by Karacaoğlu and Yörük (2012) on employees' perceptions of nepotism and organizational justice. The study by Aydın (2015), Tabancalı (2018) and Güner (2019) also found that teachers' perceptions of nepotism in school administration did not differ significantly by gender.

A significant difference was found between the teachers' perceptions of favoritism according to the "size of the school" they were in, in all sizes and on all scales. This result is similar to the results of Meriç's (2012: 51) research. This difference can be said to be due to the fact that as the number of teachers working in the school increases, it is difficult to maintain a healthy coordination and communication.

There was no significant difference between teachers 'perceptions of favoritism according to their membership in" any union". As a result of the study, whether or not teachers were members of any professional organisation did not cause any change in their perception of favoritism by administrators in the schools where they worked. In the study conducted by Aydın (2015), teachers' and school administrators' views on the dimensions of organization, evaluation, coordination and planning did not vary according to whether they were members of any union or not. However, studies conducted by Tabancalı (2018) and Güner (2019) also found no significant difference between teacher perceptions of favoritism behavior by school administrators according to the union membership variable. Karademir's (2016) study concluded that teachers who were union members had a greater perception of favoritism.

\section{F. Conclusion}

In light of the answers given by the teachers involved in the study, it was found that teachers ' perceptions of favoritism behavior towards their own school administrators were generally at the level of "sometimes". It was found that teachers ' perceptions of favoritism according to the variables "state of education", "gender", "membership in any trade union" did not differ significantly in all dimensions (planning, organization, coordination and evaluation), but significantly differed in all dimensions between their perceptions according to the variable "size of the school" in which they were located. As mentioned earlier, it can be said that this difference is caused by the fact that as the number of teachers working in the school increases, it is difficult to ensure healthy coordination and communication.

The fact that teachers express that their perceptions of favoritism behaviors of school administrators are generally at the level of "sometimes" leads to the conclusion that there is a considerable level of favoritism in schools. Because when we look at the literature, the fact that school administrators display favoritism attitudes and behaviors in their schools negatively affects teachers ' perceptions of organizational justice (Polat \&Kazak, 2014) and 


\section{Abidin Dağlı and Zühal Akyol}

organizational trust (Gülay \& Kahveci, 2020). Favoritism is a meaningful predictor of teachers ' levels of organizational silence and organizational cynicism. In this context, it is of great importance for school administrators to demonstrate management in accordance with the principles of organizational justice in order to prevent attitudes and behaviors within the scope of silence and cynicism in schools (Turhan \& Erol, 2020). It is asserted that favoritism negatively affects trust in the administrator by harming organizational justice (Kim, 2007: 103; cited in Demirtaş \& Demirbilek, 2019: 136). On the other hand, the excessive negative aspects of favoritism from the point of view of schools and teachers, such as distance from school, lack of motivation and performance, are shown as a very effective reason for teachers who are subjected to favoritism behavior, especially administrators, to experience a lack of confidence. However, it is claimed that problems such as communication problems between people, lack of cooperation and loss of consistent relationships caused by favoritism practices lead to a shake of not only the trust of employees in their administrators, but also the trust of colleagues in each other (Gülay \& Kahveci, 2020). In this context, school administrators should maintain an attitude away from favoritism by standing at an equal distance from employees in their schools. At school, administrators should treat teachers fairly, impartially and equally. Because in schools where teachers who carry the perception that school administrators display favoritism in their practices, educational activities will also be negatively affected (Meriç \& Erdem, 2013: 475). As Argon (2016:246) says, despite the negative consequences of favoritism, unfortunately, many of the employees of the institution do not speak up and have to endure in order not to lose their jobs, although they do not welcome it.

\section{G. Recommendations}

As a result of the research, teachers have stated that favoritism in their schools in general is at a "sometimes" level. This situation is quite high for the schools we call educational organizations. Intensive efforts must be made to bring this level to the "Never" rating. For this purpose, important criteria for training, selection, appointment, upgrade and evaluation of managers (finishing master's and doctorate programs in educational management, etc.) should be brought. In order to determine whether the school principals are engaged in favoritism behavior, surveys should be carried out by the Provincial and District National education directorates, which are affiliated with the school directorates, on favoritism from time to time, and one-to-one interviews should be conducted with the school administrators, if necessary, according to the results of these surveys. A transparent management approach with open channels of communication, which does not ignore value judgments such as fairness and equality, will increase teachers ' trust and commitment to their schools. For this reason, school administrators and teachers should be told about the damages of favoritism for schools through in-service training. Therefore, students will also be positively affected by these situations of teachers working with higher performance. On the other hand, as Ramanchander (2011) says, the problem of favoritism should be tried to be solved at the first stage. Otherwise, this can result in reactions such as other employees' 
disliking the workplace, withholding information, frequent discussions in the workplace, distrust, taking an attitude towards the boss or the favoured employee, etc.

On the other hand, the level of favoritism in schools at the national level can be revealed by conducting nation wide research on the subject. Public and private primary and secondary schools can be compared and research can be done. This research was conducted only with the participation of teachers. School administrators may also be included in the study, comparing perceptions of both groups. Similar research may be done using observation and interview method. However, similar research can be done in universities, too.

${ }^{1}$ This study was produced from the Master's thesis of Zühal Akyol prepared under the supervision of Assoc. Prof. Dr. Abidin Dağlı and presented as an oral presentation online at the International Pegem Education Congress (IPCEDU-2020) held on 15-18th of April, 2020 in Diyarbakır/Turkey.

\section{BIBLIOGRAPHY}

Akan, D. \& Zengin, M. (2018). The relationship between favoritism and behavior of school administrators and organizational perceptions of trust of teachers. Route Educational and Social Science Journal, 5(59), 334-345.

Argon, T. (2016). Favoritism behavior of administrators in primary schools according to teacher opinions. Kastamonu Education Journal, 24(1), 233-250.

Avetisyan, M. \& Khachatryan, V. (2014). Nepotism at schools in Armenia: A cultural perspective. Edmond J. Safra Working Papers, 51, 1-22. Retrieved from 19. 02.2021 file:///C:/Users/Abidin/Downloads/SSRN-id2523541.pdf

Aydın, Y. (2015). Relationship of organizational silence to favoritism in school management and teachers' perception of self-efficacy (Unpublished Master's Thesis). Gazi University Institute of Educational Sciences, Ankara.

Aydoğan, İ. (2009). Favoritism in the Turkish educational system: Nepotism, cronyism and patronage. Educational Policy Analysis and Strategic Research, 4(1), 19-35.

Biber, M. (2016). Public Ethical Impasse: Favoritism. Adalet Publications.

Büte, M. (2009). Nepotism in family businesses: A research on the determination of nepotism in family companies operating in Trabzon province. 17th proceedings of the national congress of management and organization,737-741. Retrieved from 19. 02. 2019 (http://wz.balikesir.edu.tr/ seymen/yonetim.pdf).

Cesur, A. \& Erol, E. (2020). The relationship between nepotism and organizational justice in school administration: The case of Afyonkarahisar Province. OPUS-International Journal of Community Studies, 15(25), 3467-3496.

Coco, G., \& Lagravinese, R. (2014). Cronyism and education performance. Economic Modelling, 38, 443-450. Retrieved from 08.03. 2019. file:///C:/Users/Abidin/Downloads/1-s2.o-So264999314000418-main.pdf 
Abidin Dağlı and Zühal Akyol

Çelik, K. \& Erdem, A. R. (2012). Nepotism, according to administrative staff at the University. Mediterranean Journal of Educational Research, 6(11), 23-30.

Çevikbaş, R. (2006). Ethics and corruption in management. Journal of Economics and Administrative Sciences, 20 (1), 265-289.

Demaj, E. (2012). Nepotism, favoritism and cronyism and their effects on organizational trust and commitment: The case of the service sector in Albania (Unpublished master's thesis). Epoka University, Arnavutluk.

Demirtaş, H. \& Demirbilek, N. (2019). Effect of nepotism behavior of school principals on teachers' perceptions of organizational justice and trust in the principal. Bingol University Journal of the Institute of Social Sciences, 9(17), 111-142.

Erdem, R. (2010). Favoritism in terms of Management and Organization. Beta Publication.

Erdem, M. \& Meric, E. (2012). Scale development study on favoritism in school administration. Journal of Educational Sciences Research, 2(2), 141-154.

Erdem, M., Aytaç, T. \& Gönül. T. (2020). The Relationship between teachers' perceptıon of organızational cynicism and school. European Journal of Education Studies, 7(6),1-21.

Gider, İ. (2020). The relationship between nepotism behaviors in school administration and the levels of alienation of teachers to work (Unpublished master's thesis). Siirt University Institute of Social Sciences, Siirt.

Gülay, S. S. \& Kahveci, G. (2020). The relationship between teachers' perceptions of nepotism and organizational confidence levels. Mediterranean Journal of Educational Research, 14(33), 494-522.

Güner, N. (2019). Relationship between nepotism behavior of school administrators and life satisfaction of teachers (Example of Diyarbakır Province) (Unpublished Master's Thesis). Dicle University, Institute of Educational Sciences, Diyarbakir.

Jones, R.E. (1997). Teacher participation in decision making: Its relation ship to staff morale and students achievement. Education, 118(1), 76-83.

Kahraman, Ü. (2020). Favaoritism behaviors of school principals. Uşak University Journal of Educational Research, 6(3), 90-106.

Karasar, N. (2006). Scientific Research Methods. Nobel Publications.

Karacaoğlu, K. \& Yörük, D. (2012). Employees' perceptions of nepotism and organizational justice: a family business practice in central anatolia. Journal of Business, Power Industrial Relations and Human Resources, 14(3), 43-64.

Karademir, M. (2016). Examination of the relationship between favoritism perceptions and organizational cynicism in school management of secondary school teachers: the case of pendik district of ıstanbul (Unpublished master's thesis). İstanbul Aydın University, İstanbul

Karakaş, M. \& Çak, M. (2007). The role of international organizations in the fight against corruption. Journal of Finance, (153), 74-101.

Kartal, N. \& Demirhan, Y. (2009). Neutrality in Turkish public administration. Journal of Turkish Administration, (462), 169-177.

Khatri, N.,Tsang, E. W. \& Begley, T. M. (2006). Cronyism: A cross-culturalanalysis. Journal of International Business Studies, 37(1), 61-75. 
Kolukırık, L. (2019). Teacher perceptions of favoritism behavior of school administrators (Example of altindag district of Ankara province) (Unpublished master's thesis). Gazi University. Institute of Educational Sciences, Ankara.

Longman, L. (2004). Longman Dictionary of English Idioms. Longman.

Meriç, E. (2012). Favoritism in School Management According to Perceptions of Teachers Employed in Primary Schools. (Unpublished Master's Thesis) Yüzüncü Yıl University Institute of Social Sciences, Van.

Meriç, E. \& Erdem, M. (2013). Favoritism in School Management According to the perceptions of teachers working in primary schools. Education Management in Theory and Practice, 19(3), 467-498.

Nabiryo, S. K. (2016). Nepotism and school performance: A case study of Kasenge Greenhill secondary school in Kampala district, Uganda. Thesis (Masters). Islamic Universityi in Uganda. Retrieved from 21.03.2021. http://www.ir.iuiu.ac.ug/bitstream/handle/20.500.12309/309/NABIRYO\%20SHAMIRA H\%20KASAULI.pdf? sequence=1\&isAllowed $=y$

Nadler, J. \&Schulman, M. (2006). Favoritism, cronyism, and nepotism. Retrieved from 19. 02. 2019 https://www.scu.edu/government-ethics/resources/what-is-governmentethics/favoritism-cronyism-and-nepotism/.

Özkanan, A. \& Erdem, R. (2014). Favoritism practices n management: a conceptual framework. Suleyman Demirel University Journal of Social Sciences, 2(20),179-206.

Özsemerci, K. (2003). Corruption In Turkish public administratiion, its causes, damages and solution proposals. T. C Court of Accounts/ Research / Review / Translation Sequence: 27. Retrieved from

19.02.2018. (https://www.sayistay.gov.tr/tr/Upload/95906369/files/yayinlar/TurkKamuYonetimind e_Yolsuzluklar.pdf).

Polat, S. \& Kazak, E. (2014). The relationship between nepotistic attitutes and behaviors of school administrators and teachers' perceptions of organizational justice. Education Managementi in Theory and Practice, 20(1), 71-92.

Pounder, D. G. \& Blase, J. J. (1988). Principal favoritism: Explanations, effects, andimplications for practice. University of Central Arkanasas Interlibrary Loan. Retrieved from $19 . \quad 03 . \quad 2020$ https://www.researchgate.net/publication/265851199_Principal_favoritism_Explanati ons_effects_and_implications_for_practice

Ramachander, A. (2011). Dealing with favoritism at the workplace. Retrieved from 19. 02. 2019 http://www.deccanherald.com/content/173905/dealing-favouritismworkplace.html

Sheridan, M. K. (2007). Just because it's sex doesn't mean it's because of sex: The need for new legislation to target sexual favoritism. Retrieved from 19. 02.2019. (https://heinonline.org/HOL/Page?collection=journals\&handle=hein.journals/collsp40 \&id=391\&men_tab=srchresults).

Tabancalı, E. (2018). Nepotism in primary schools. International Online Journal of Educational Sciences, 10(2), 162-175. 
Abidin Dağlı and Zühal Akyol

Tarhan, R. B., Gençkaya, Ö. F., Ergül, E., Özsemerci, K. \& Özbaran, H. (2006). AntiCorruption-parliamentary report. Corruption as a phenomenon: Causes, effects and solutions. Retrieved from 21.02.2018 https://www.tepav.org.tr/upload/files/13134754134.Bir_Olgu_Olarak_Yolsuzluk_Nede nler_Etkiler__Cozum_Onerileri.pdf

Turgut, K. (2007). Impact of political corruption on human behavior. Retrieved from on 24.02. 2017. https://sites.google.com/site/grandustadakademi/politik-yozlasmanin-insanvezerindeki-etkisi

van Hooft, E. A. J., \& Stout, T. (2012). Nepotism and career choice, job search, and job choice. In R. G. Jones (Ed.), Nepotism in organizations (pp. 67-91). Routledge/Taylor \& Francis Group.

Yıldırım, M. (2013). The ancient paradox of public administration: Nepotism and meritocracy. Celal Bayar University Journal of Social Sciences, 11(2), 353-380. 